Artikel Penelitian

\title{
Pengaruh Steam Blanching terhadap Aktivitas Polifenol Oksidase, Total Polifenol, dan Aktivitas Antioksidan Biji Kakao
}

\section{Steam Blanching Effect on Polyphenol Oxidase Activity, Total Polyphenol Content, and Antioxidant} Activity of Cocoa Bean

Nurhayati $^{{ }^{*}}$, Djagal Wiseso Marseno ${ }^{2}$, Francis M Constance Sigit Setyabudi ${ }^{2}$, Supriyanto $^{2}$

${ }^{1}$ Program Studi Teknologi Hasil Pertanian, Fakultas Pertanian, Universitas Muhammadiyah Mataram

${ }^{2}$ Program Studi Ilmu Pangan, Fakultas Teknologi Pertanian, Universitas Gadjah Mada, Yogyakarta

*korespondensi penulis (nurhayati.faperta.ummat@gmail.com)

Artikel ini dikirim pada tanggal 2 Maret 2018 dan dinyatakan diterima tanggal 23 Agustus 2018. Artikel ini juga dipublikasi secara online melalui https://ejournal2.undip.ac.id/index.php/jatp. Hak cipta dilindungi undang-undang. Dilarang diperbanyak untuk tujuan komersial.

Diproduksi oleh Indonesian Food Technologists® @2018

\begin{abstract}
Abstrak
Penelitian ini bertujuan untuk untuk mengetahui pengaruh steam blanching terhadap aktivitas polifenol oksidase, total polifenol, dan aktivitas antioksidan biji kakao. Bii kakao segar yang telah dihilangkan pulpnya ditimbang sebanyak 100 dan $200 \mathrm{~g}$ kemudian masing masing massa biji kakao diberi perlakuan steam blanching selama 1, 3, dan 5 menit. Biji kakao steam blanching dianalisa karakteristik fisikokimia (kadar air, pH, warna dan suhu), gugus fungsional (FTIR), aktivitas polifenol oksidase (PPO), kandungan total polifenol, dan aktivitas antioksidan. Hasil penelitian menunjukkan bahwa steam blanching dengan perlakuan kombinasi antara massa 100 $\mathrm{g}$ dan lama 1 menit menyebabkan menurunnya aktivitas PPO dari 445,87 menjadi 11,28 U/g berat biji kakao segar (FW), meningkatkan kandungan total polifenol dari 72,63 menjadi 92,15 mg Ekuivalen Asam Galat (EAG)/g bubuk kakao bebas lemak (DS), dan meningkatkan aktivitas penangkapan radikal bebas DPPH dari 55,36 \% menjadi 68,99 $\%$ atau dengan nilai $\mathrm{IC}_{50}$ dari 3,39 menjadi $2,58 \mathrm{ml} / \mathrm{l}$ apabila dibandingkan dengan kontrol (tanpa steam blanching). Aktivitas antioksidan pada biji kakao steam blanching juga lebih tinggi dibandingkan antioksidan sintetis seperti BHT dan asam askorbat. Kesimpulannya, steam blanching dapat menurunkan aktivitas PPO, meningkatan kandungan total polifenol dan meningkatkan aktivitas antioksidan. Oleh karena itu, perlakuan steam blanching dapat dijadikan sebagai salah satu alternatif proses pengolahan dalam mempertahankan antioksidan alami polifenol biji kakao.
\end{abstract}

Kata kunci: biji kakao, steam blancing, polifenol oksidase, polifenol, aktivitas antioksidan

\begin{abstract}
The aim of this research were to determine the effect of steam blanching on the activity of polyphenol oxidase, total polyphenol content, and antioxidant activity of cocoa beans. The fresh cocoa beans that have been removed the pulp were 100 and $200 \mathrm{~g}$ and then each cocoa beans mass was treated with steam blanching for 1, 3, and 5 minutes. Physicochemical characteristics (moisture content, $\mathrm{pH}$, color, and temperature), functional group, polyphenol oxidase (PPO) activity, total polyphenol content and antioxidant activity of cocoa beans were observed. The results showed that steam blanching by treatment (100 g; $1 \mathrm{~min}$ ) decreased of the PPO activity from 445.87 to $11.28 \mathrm{U} / \mathrm{g}$ of fresh weight (FW), increased total polyphenol content from 72.63 to $92.15 \mathrm{mg}$ of Equivalent Galic Acid (EAG)/g defatted sample (DS), increased RSA DPPH from $55.36 \%$ to $68.99 \%$ or with $1 C_{50}$ value from 3.39 to 2.58 $\mathrm{ml} / \mathrm{l}$ when compared to the control (without steam blanching). Antioxidant activity of steamed blanching cocoa beans also were detected higher than the synthetic antioxidants such as BHT and ascorbic acid. As conclusion, the steam blanching treatment might decrease the PPO activity, increase the total polyphenol content, and increase of antioxidant activity. Therefore, the steam blanching treatment could be used as an alternative process for preserving natural antioxidant of cocoa bean polyphenols.
\end{abstract}

Keywords: cocoa bean, steam blancing, polifenol oksidase, polyphenol, antioxidant activity

\section{Pendahuluan}

Seiring dengan perubahan pola hidup masyarakat, produk kakao seperti cokelat tidak hanya disukai karena cita-rasanya akan tetapi karena adanya kandungan polifenol yang bermanfaat bagi kesehatan. Beberapa peneliti telah melakukan kajian tentang potensi polifenol kakao sebagai antioksidan alami yang bermanfaat bagi kesehatan seperti menjaga kesehatan kulit, memulihkan unit neurovaskuler, peradagangan usus, menjaga system imun (Magrone et al., 2017), mencegah penyakit kardiovaskuler, kanker payudara (Scapagnini et al., 2014).
Senyawa polifenol pada biji kakao terdiri atas katekin atau flavan-3-ols $( \pm 37 \%)$, antosianin $( \pm 4 \%)$ dan proantosianidin $( \pm 58 \%)$ (Wollgast dan Anklam, 2000). Senyawa polifenol yang terkandung pada biji kakao kering sebanyak $5-18 \%$ atau $0,5-1,8 \mathrm{mg} / \mathrm{g}$ (loannou et al., 2012). Dalam proses pengolahan biji kakao segar sampai menjadi produk cokelat, senyawa polifenol banyak mengalami pengurangan. Pengurangan tersebut diakibatkan oleh adanya proses fermentasi dan pengeringan. Penelitian yang dilakukan oleh TomasBarberán et al. (2007) menyebutkan bahwa senyawa polifenol pada biji kakao kering yang telah difermentasi 
berkurang dari 7,8 g/100 g menjadi $4 \mathrm{~g} / 100 \mathrm{~g}$ berat kering atau hampir mencapai $50 \%$. Hal yang sama juga dilaporkan oleh (Misnawi et al., 2002) bahwa fermentasi biji kakao segar selama 5 hari dapat menurunkan senyawa polifenol $\pm 53,4 \%$ dari polifenol awal sebesar $135,1 \mathrm{~g} / \mathrm{kg}$ menjadi $72,1 \mathrm{~g} / \mathrm{kg}$. Camu et al. (2008) juga menyebutkan bahwa penurunan senyawa polifenol mencapai 10-50 \%. Hal yang serupa disebutkan oleh (Bonvehi dan Coll, 1997) bahwa kandungan senyawa polifenol turun sebesar $\pm 63 \%$ dari $150 \mathrm{mg} / \mathrm{g}$ menjadi 55 $\mathrm{mg} / \mathrm{g}$. Hal tersebut kemungkinan disebabkan oleh senyawa polifenol biji kakao yang teroksidasi karena reaksi enzimatis serta didukung oleh adanya oksigen dan kadar air biji masih berkisar 10-40\%.

Dalam meminimalisir terjadinya pengurangan senyawa polifenol, maka perlu dihambat sejak awal pada biji kakao segar dengan menggunakan perlakuan pemanasan seperti blanching. Penggunaan blanching telah banyak dilakukan pada berbagai komoditas seperti pada jus kiwi (Benlloch-Tinoco et al., 2013), kubis (AbuGhannam dan Jaiswal, 2015), sedangkan pada biji kakao telah dilaporkan oleh Tomas-Barberán et al. (2007) dan Menon et al. (2015) menggunakan metode water blanching. Akan tetapi penggunaan water blanching memiliki kerugian seperti kehilangan vitamin, flavor, warna, tektur, karbohidrat, dan beberapa senyawa yang larut air serta menjadi limbah (Queiroz et al. 2008; Xiao et al. 2017). Hal tersebut terjadi pada beberapa komoditas seperti strawberry (Terefe et al., 2010), bayam, wortel dan kembang kol (Mazzeo et al., 2011), sayuran berdaun hijau (Bamidele et al., 2017). Oleh karena itu, penelitian ini bertujuan untuk mengetahui pengaruh steam blanching terhadap aktivitas polifenol oksidase, total polifenol dan aktivitas antioksidan biji kakao. Penelitian ini diharapkan dapat dijadikan sebagai referensi salah satu alternative proses pengolahan biji kakao pada berbagai industri khususnya yang mengembangkan produk kesehatan berbasis antioksidan alami polifenol kakao

\section{Materi dan Metode \\ Materi}

Bahan yang digunakan adalah buah kakao lindak sehat dan sudah masak fisiologis, buah diperoleh dari perkebunan petani kakao di Dusun Gambiran, Desa Bunder, Kecamatan Patuk, Kabupaten Gunung kidul, Yogyakarta. Bahan kimia yang digunakan dalam penelitian ini adalah aquabidest, aquadest, kertas saring whatman \#1 diameter $90 \mathrm{~mm}$, buffer $\mathrm{Na}$-asetat-Asam asetat ( $\mathrm{pH}$ 5.0), heksan pro analisis, aseton pro analisis $80 \%$, reagen Folin-Ciocalteu, natrium karbonat 15\%, standar asam galat, 11-diphenyl-2-picrylhydrazyl (DPPH), standar BHT, standar asam askorbat dan katekol (pyrocatechol) 0,5 M dari Sigma Aldrich, Singapura. Adapun Alat yang digunakan pada penelitian ini adalah termokopel type K, Chromameter (CR-200 Japan), spektrofotometer (Spectronic 200 Thermoscientific), rotary evaporator, alat FTIR 100 Perkin Elmer, sonikator (Sibata SU-2TH 100W 50/60Hz), $\mathrm{pH}$ meter, eksikator, pengering kabinet dryer, panci pengukus merk Djawa diameter $20 \mathrm{~cm}$.

\section{Metode}

Penelitian berlangsung dari bulan Juli sampai November 2015. Pelaksanaan penelitian meliputi persiapan alat dan bahan, proses steam blanching biji kakao, pengamatan dan analisa yang meliputi analisa fisikokimia (kadar air, $\mathrm{pH}$, warna, suhu, persentase perubahan massa), analisa aktivitas PPO, total polifenol, aktivitas antioksidan, dan gugus fungsi.

\section{Persiapan bahan dan alat}

Persiapan bahan diawali dengan membelah buah kakao dengan pemukul kayu lalu diambil bijinya. Biji kakao dihilangkan pulpnya secara manual, lalu ditimbang sebanyak 100 dan $200 \mathrm{~g}$. Persiapan alat diawali dengan memanaskan air sebanyak $1500 \mathrm{ml}$ di dalam steamerselama 10 menit (sampai mendidih).

\section{Proses steam blancing biji kakao}

Proses steam blanching mengikuti cara yang dilakukan oleh Nurhuda et al. (2013) yang telah dimodifikasi. Biji kakao dengan massa 100 dan $200 \mathrm{~g}$ dipanaskan didalam steamer (panci pengukus) secara bergantian dengan 3 interval lama pemanasan yakni 1, 3 , dan 5 menit per masing-masing berat bahan. Setiap melakukan proses steam blanching, air didalam panci diganti. Masing-masing perlakuan diulang sebanyak 3 kali. Setelah mencapai lama pemanasan tersebut secara cepat diukur suhu biji yang sebelumnya telah disetting termokople pada panci pengukus. Biji kakao hasil pemanasan diukur massanya kemudian sebagian dianalisa ( $\mathrm{pH}$, kadar air, aktivitas PPO) dan sebagian dikeringkan dengan menggunakan cabinet dryer pada suhu $55^{\circ} \mathrm{C}$ hingga kadar air biji kakao mencapai 6-8 \%. Biji kakao yang telah kering dianalisa warna, kandungan total polifenol, dan aktivitas antioksidan.

\section{Pengukuran suhu, kadar air dan $\mathrm{pH}$}

Pengukuran suhu dilakukan dengan menggunakan termokople dimana sensor termokople dimasukkan kedalam panci yang telah dilubangi tutupnya, selama pemanasan suhu biji kakao diukur suhunya sampai mencapai suhu maksimal. Analisa kadar air dilakukan dengan metode thermogravimetri (AOAC,1995), sedangkan untuk $\mathrm{pH}$ dilakukan berdasarkan pada metode SNI biji kakao (2008). Analisa kadar air dilakukan berdasarkan pada prosedur sebelumnya (AOAC, 1995). Pengukuran pH sampel dilakukan berdasarkan pada standard pengukuran $\mathrm{pH}$ (SNI, 2008) dengan menggunakan $5 \mathrm{~g}$ biji kakao yang telah dipanaskan pada berbagai variasi berat dan lama pemanasan lalu dihomogenisasi dalam $100 \mathrm{ml}$ air panas selama 30 detik, yang kemudian disaring dengan kertas saring Whatman no.4. Filtrat yang telah diperoleh dianalisis $\mathrm{pH}$ nya.

\section{Pengujian aktivitas PPO}

Pengujian aktivitas PPO dilakukan mengikuti cara yang dilakukan oleh Putra et al. (2012). Biji kakao segar yang telah diberi perlakukan steam blanching, dihancurkan sampai halus lalu ditimbang sebanyak $10 \mathrm{~g}$ dan ditambahkan $20 \mathrm{ml}$ aquabidest. Campuran tersebut 
dihomogenisasi menggunakan stirer pada suhu $0^{\circ} \mathrm{C}$ selama 10 menit lalu disaring dengan kertas saring Whatman\#1 dengan menggunakan pompa vakum. Filtrat yang diperoleh berupa PPO ditampung pada botol valcon kemudian dikarakterisasi yakni dengan cara diambil PPO sebanyak $0,1 \mathrm{ml}$, lalu ditambahkan dengan 2,6 $\mathrm{ml}$ buffer $\mathrm{Na}$-asetat-Asam asetat $(\mathrm{pH} \mathrm{5,0)}$ dan $0,3 \mathrm{ml}$ substrat katekol $0,5 \mathrm{M}$ pada suhu $25^{\circ} \mathrm{C}$. Campuran tersebut kemudian dibaca absorbansinya menggunakan spektrofotometer pada $\lambda 420 \mathrm{~nm}$. Pembacaan absorbansi dilakukan selama 3 menit dengan selang waktu baca 1 menit. Satu unit (U) aktivitas PPO sama artinya dengan perubahan absorbansi sebesar 0,001 per menit. Selanjutnya satuan U per volume $(\mathrm{ml})$ enzim yang digunakan dalam pengujian dikonversi menjadi satuan $U$ per gram biji kakao segar (FW). Pengujian tersebut dilakukan sebanyak 3 kali ulangan.

\section{Pengukuran warna}

Pengukuran warna dilakukan mengikuti cara yang dilakukan oleh Supriyanto et al. (2014). Biji kakao kering hasil perlakuan pemanasan dihaluskan dengan menggunakan mortar lalu sampel halus dimasukkan kedalam glass kaca kemudian diukur dengan cromameter (merk Minolta CR-200, Jepang). Dicatat nilai-nilai warna $L^{*}$, $a^{*}$ dan $b^{*}$. Warna $L^{*}$ (lightness) menyatakan tingkat kecerahan, warna $a^{\star}$ menyatakan nilai perubahan warna hijau ke merah dan warna $b^{*}$ menyatakan nilai perubahan warna biru ke kuning. Pembacaan dilakukan lima kali pada masing-masing sampel dan diulang sebanyak tiga kali pada masingmasing perlakuan.

\section{Analisa kandungan total polifenol}

Kandungan total polifenol dianalisa mengikuti cara yang dilakukan oleh Noor-Soffalina et al. (2009) dengan sedikit modifikasi. Sampel biji kakao kering yang telah dihilangkan lemaknya melalui metode soxhlet sebanyak $0,5 \mathrm{~g}$ diesktrak dengan menggunakan $100 \mathrm{ml}$ aseton : air (80: $20 \mathrm{v} / \mathrm{v}$ ) kemudian disonikasi dengan frekuensi 50$60 \mathrm{~Hz}$ menggunakan sonikator pada suhu $4^{\circ} \mathrm{C}$ selama 30 menit, lalu disaring menggunakan pompa vakum. Ekstrak sampel dihilangkan asetonnya menggunakan rotary evaporator. Sebanyak $1 \mathrm{ml}$ ekstrak sampel dilarutkan hingga volume $10 \mathrm{ml}$ dengan aseton $80 \%$. Ekstrak kemudian diambil sebanyak $1 \mathrm{ml}$ dan ditambahkan $7 \mathrm{ml}$ aquades yang kemudian direaksikan dengan $0,5 \mathrm{ml}$ reagen Folin-Ciocalteu (1:1 aquades) diamkan selama 2-3 menit, kemudian ditambahkan $1 \mathrm{ml}$ natrium karbonat $15 \%$ (15 g dilarutkan dengan aquades) lalu divorteks. Larutan diinkubasi selama 2 jam pada suhu kamar, kemudian sampel diukur absorbansinya menggunakan panjang gelombang $765 \mathrm{~nm}$. Hasil kandungan total polifenol disajikan dalam miligram ekuivalen asam galat per gram sampel bubuk kakao bebas lemak sehingga diperoleh persamaan kurva standar dari larutan asam galat dengan konsentrasi kisaran 1-100 mg/l (ppm).

Analisa aktivitas penangkapan radikal bebas 1,1diphenyl-2-picrylhydrazyl

Aktivitas penangkapan radikal bebas 1,1diphenyl-2-picrylhydrazyl (DPPH) mengikuti cara yang dilakukan oleh Burda dan Oleszek (2001) dengan sedikit modifikasi. Larutan ekstrak dibuat dengan konsentrasi 5-40 ml/l. Larutan ekstrak tersebut diambil sebanyak 1 $\mathrm{ml}$ kemudian ditambahkan $2 \mathrm{ml}$ larutan DPPH 0,1 mM (DPPH dalam methanol). Campuran divorteks dan ditera pada panjang gelombang $517 \mathrm{~nm}$ dengan spektrofotometer, kemudian didiamkan selama 30 menit pada suhu kamar diruang gelap, lalu ditera pada panjang gelombang $517 \mathrm{~nm}$. Aquadest $80 \%$ digunakan sebagai kontrol, BHT dan asam askorbat digunakan sebagai pembanding. Perbedaan absorbansi sampel dan kontrol menunjukkan efektivitas penangkapan radikal DPPH. Persentase Aktivitas penangkapan radikal bebas dihitung dengan membagi antara hasil pengurangan absorbansi kontrol dan absorbansi sampel, dengan absorbansi kontrol dikalikan 100 persen. Aktivitas antioksidan sebagai penangkap radikal bebas dinyatakan sebagai persentase pada konsentrasi ekstrak $40 \mathrm{ml} / \mathrm{l}$ dan juga sebagai $\mathrm{IC}_{50}(\mathrm{ml} / \mathrm{l})$ yang menunjukkan konsentrasi yang dapat memberikan penghambatan terhadap radikal bebas DPPH sebesar $50 \%$.

\section{Analisa gugus fungsional}

Sampel sebanyak $1 \mathrm{mg}$ digerus bersama-sama dalam 200 mg KBr hingga bercampur secara sempurna, kemudian ditekan dengan cakram tipis atau pelet. Pelet ini kemudian dianalisa menggunakan alat FTIR 100 Perkin Elmer dengan rentang panjang gelombang 4000$400 \mathrm{~cm}^{-1}$ sehingga diperoleh spektrum.

Tabel 1. Karakteristik Fisikokimia Biji Kakao Steam Blanching

\begin{tabular}{|c|c|c|c|c|c|c|c|}
\hline \multirow{2}{*}{$\begin{array}{l}\text { Massa } \\
\text { (g) }\end{array}$} & \multirow{2}{*}{$\begin{array}{l}\text { lama } \\
\text { (menit) }\end{array}$} & \multirow{2}{*}{$\begin{array}{c}\text { Kadar air } \\
\%\end{array}$} & \multirow[t]{2}{*}{ Suhu $\left({ }^{\circ} \mathrm{C}\right)$} & \multirow[t]{2}{*}{$\mathrm{pH}$} & \multicolumn{3}{|c|}{ Warna } \\
\hline & & & & & $L^{*}$ & $a^{*}$ & $b^{*}$ \\
\hline & 1 & $33,27 \% \pm 1,48 \%{ }^{b c}$ & $94,1 \pm 1,4^{\mathrm{C}}$ & $7,09 \pm 0,02^{b}$ & $36,71 \pm 0,81^{b}$ & $8,72 \pm 0,20^{b}$ & $-1,64 \pm 0,13^{\mathrm{e}}$ \\
\hline \multirow[t]{2}{*}{100} & 3 & $34,09 \% \pm 0,57 \%{ }^{b}$ & $98,9 \pm 0,2^{\mathrm{e}}$ & $7,16 \pm 0,04^{\mathrm{cd}}$ & $36,73 \pm 0,89^{b}$ & $9,03 \pm 0,37^{b}$ & $-1,32 \pm 0,35^{c d}$ \\
\hline & 5 & $34,38 \% \pm 1,47 \%{ }^{b}$ & $99,4 \pm 0,1^{\mathrm{e}}$ & $7,49 \pm 0,07^{\mathrm{e}}$ & $38,21 \pm 1,73^{b}$ & $8,83 \pm 0,57^{b}$ & $-0,76 \pm 0,60^{b c}$ \\
\hline \multirow[t]{3}{*}{200} & 1 & $34,31 \% \pm 1,95 \%{ }^{b}$ & $91,8 \pm 0,4^{b}$ & $7,08 \pm 0,01^{b}$ & $37,76 \pm 4,3^{b}$ & $8,81 \pm 1,53^{a b}$ & $-0,82 \pm 0,13^{b c}$ \\
\hline & 3 & $30,78 \% \pm 0,81 \%^{\mathrm{cd}}$ & $97,2 \pm 0,6^{d}$ & $7,11 \pm 0,02^{b c}$ & $37,76 \pm 2,52^{b}$ & $8,86 \pm 0,80^{b}$ & $-0,38 \pm 0,37^{b}$ \\
\hline & 5 & $28,54 \% \pm 1,09 \%{ }^{d}$ & $99,5 \pm 0,2^{\mathrm{e}}$ & $7,19 \pm 0,02^{d}$ & $35,79 \pm 2,06^{b}$ & $8,27 \pm 0,68^{a b}$ & $-1,20 \pm 0,29^{c d}$ \\
\hline Kontrol & & $55,07 \% \pm 1,97 \%^{a}$ & $25,4 \pm 1,3^{\mathrm{a}}$ & $6,59 \pm 0,03^{a}$ & $44,62 \pm 0,23^{a}$ & $6,89 \pm 0,25^{a}$ & $1,08 \pm 0,25^{a}$ \\
\hline
\end{tabular}

- Data disajikan dalam rata-rata \pm standar deviasi dari 3 kali ulangan perlakuan dan analisa.

- Huruf yang berbeda menunjukkan tingkat perbedaan yang nyata pada tingkat signifikansi 95\% dengan uji DMRT. 


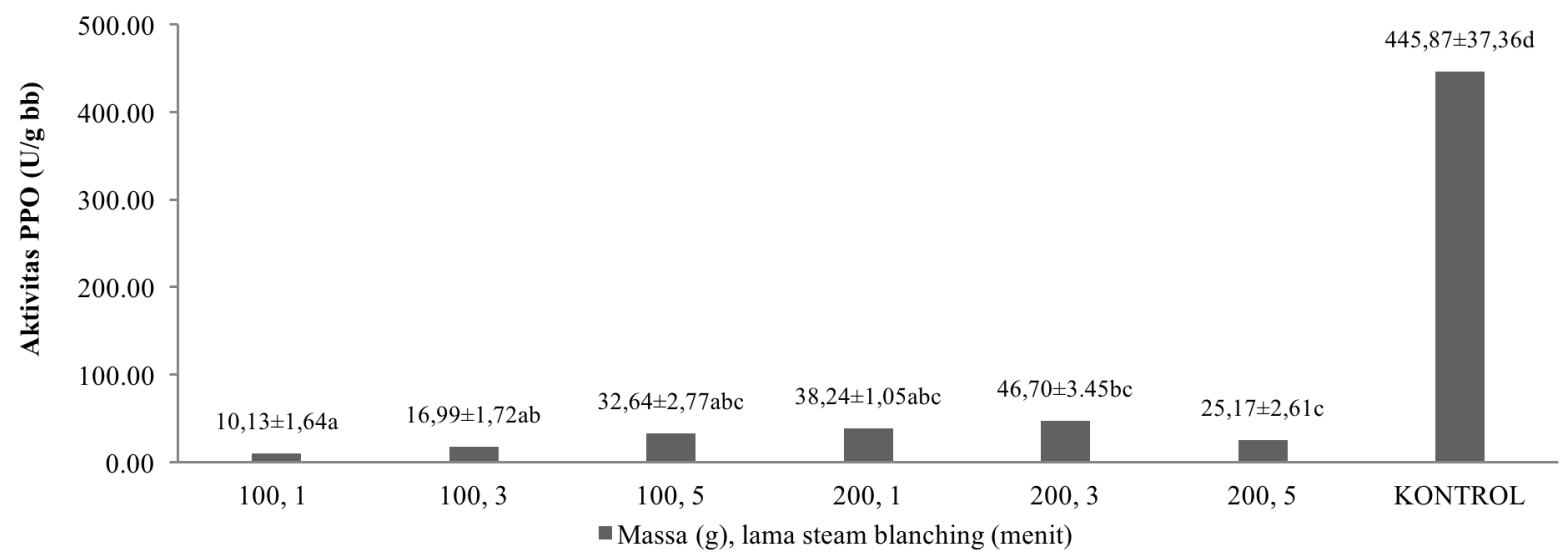

Figur 1. Aktivitas Polifenol oksidase (PPO) biji kakao akibat perlakuan kombinasi variasi massa dan lama steam blanching.

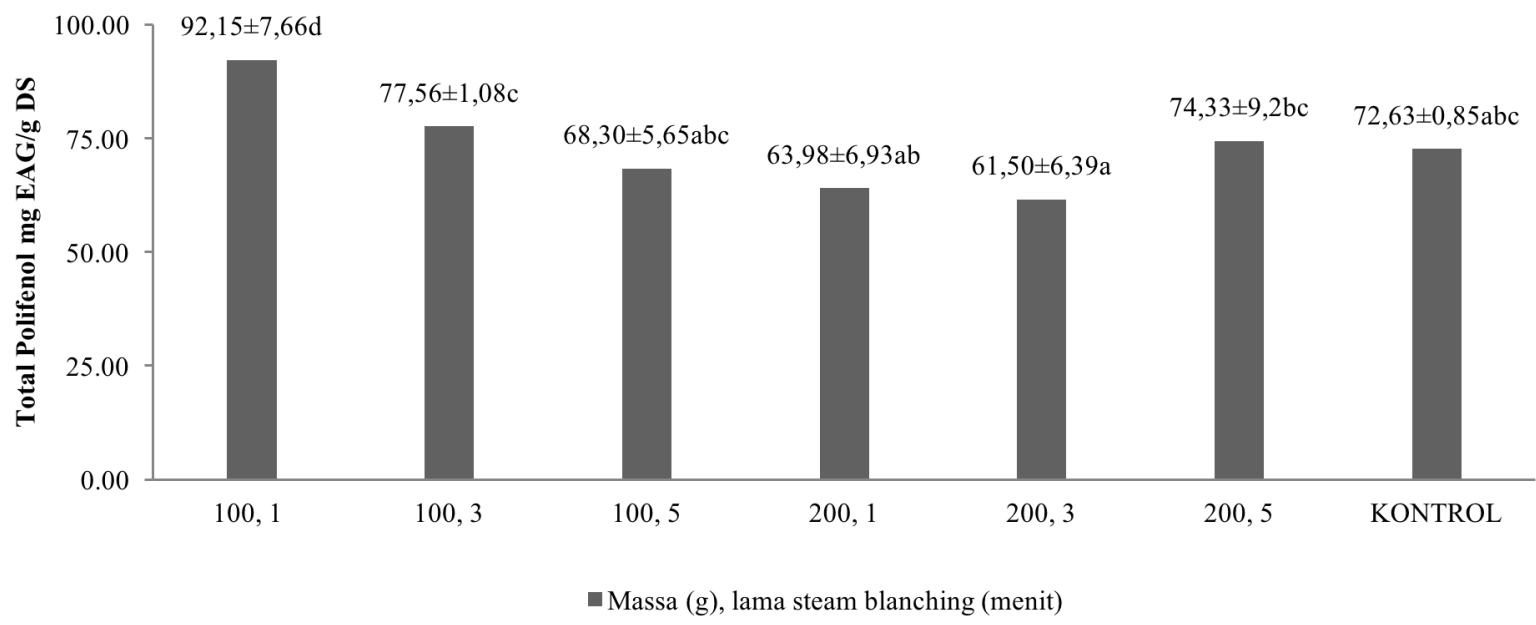

Figur 2. Kandungan total polifenol biji kakao akibat perlakuan kombinasi variasi massa dan lama steam blanching

\section{Hasil dan Pembahasan}

Karakteristik fisikokimia biji kakao steam blanching Hasil penelitian karakteristik fisikokimia pada biji kakao yang telah mengalami perlakuan steam blanching disajikan pada Tabel 1. Karakteristik fisikomia yang diamati meliputi kadar air, $\mathrm{pH}$, suhu biji, dan warna. Hasil analisa kadar air biji kakao yang telah mengalami steam blanching berkisar antara 28,54-34,38\%. Perubahan kadar air pada perlakuan kombinasi variasi massa 100 dan $200 \mathrm{~g}$ dengan lama steam blanching 1, 3, dan 5 menit tidak mengalami perbedaan yang nyata. Namun perbedaan nyata terlihat dengan biji kakao kontrol sebesar 55,07\%. Penurunan kadar air dipengaruhi oleh energi panas dari steamer seiring dengan peningkatan lama steam blanching sehingga menyebabkan terjadinya proses pindah massa yang terjadi dalam sistem biji kakao ke permukaan biji kakao selanjutnya ke lingkungan biji kakao (Amanto et al., 2015). Selain proses penguapan tersebut, diduga penurunan kadar air juga erat hubungannya dengan peranan air yang mempengaruhi laju reaksi yang terjadi selama proses blanching (Ayu dan Yuwono, 2013).

Pada parameter suhu biji, tampak bahwa suhu biji mengalami peningkatan seiring dengan lamanya perlakuan steam blanching pada kombinasi variasi massa 100 dan $200 \mathrm{~g}$, namun peningkatan suhu lebih besar terjadi pada perlakuan massa $100 \mathrm{~g}$. Hal ini dikarenakan penyerapan panas maksimal terjadi pada massa biji yang lebih rendah. Suhu biji kakao steam blanching berkisar antara $91,8-99,5^{\circ} \mathrm{C}$. Apabila dibandingkan dengan suhu biji kakao kontrol adalah $25,4^{\circ} \mathrm{C}$. Adapun hasil pengukuran $\mathrm{pH}$ biji kakao steam blanching berkisar antara 7,08-7,49 dan bila dibandingkan kontrol adalah 6,59.

Warna dapat diapresiasikan sebagai indikator untuk menilai tingkat keparahan dan memprediksi degradasi kualitas nutrisi bahan akibat perlakuan proses blanching (Xiao et al., 2017). Pengukuran warna berdasarkan nilai $L^{*}, a^{*}, b^{*}$. Nilai $L^{*}$ menunjukkan tingkat kecerahan, nilai $a^{\star}$ menunjukkan nilai pengukuran warna dari hijau ke merah dan nilai $b^{\star}$ menunjukkan nilai pengukuran warna dari biru ke kuning. Dari tabel tersebut terlihat bahwa nilai $L^{*}$ mengalami penurunan setelah diberi perlakuan steam blanching. Hal ini menunjukkan bahwa biji kakao kontrol lebih gelap dibandingkan biji kakao steam blanching. Nilai $L^{*}$ biji kakao steam blanching berkisar antara 35,79-38,21 apabila dibandingkan dengan kontrol yakni 44,62. Hal yang sama juga ditunjukkan oleh nilai a* pada perlakuan steam blanching dengan kontrol dimana nilai a biji kakao steam blanching lebih besar dari kontrol yakni dengan kisaran 8,27-9,03, sedangkan nilai $a^{*}$ pada kontrol 
adalah 6,89. Hal ini menunjukkan bahwa warna biji kakao steam blanching lebih kemerahan dibandingkan kontrol. Berlawanan halnya dengan nilai $b^{*}$ yang berbeda nyata antara perlakuan steam blanching dan kontrol. Nilai $b^{*}(-)$ pada biji kakao steam blanching menunjukkan warna biru yang lebih tinggi dibandingkan nilai $b^{*}(+)$ pada kontrol. Hal yang sama disampaikan oleh Xiao et al. (2017) bahwa bahan yang tanpa perlakuan blanching menunjukkan penurunan yang tajam terhadap nilai $L$ dan peningkatan terhadap warna kemerahan $\left(a^{\star}\right)$ dan kekuningan $\left(b^{\star}\right)$.

\section{Aktivitas polifenol oksidase biji kakao steam blanching} Hasil penelitian aktivitas polifenol oksidase (PPO) pada biji kakao steam blanching dengan kombinasi variasi massa dan lama steam blanching disajikan pada Figur 1. Aktivitas PPO biji kakao steam blanching berbeda nyata bila dibandingkan dengan kontrol. Dari figur tersebut terlihat bahwa perlakuan steam blanching mengakibatkan penurunan aktivitas PPO dengan kisaran 11,28-31,41 U/g (FW) dari kontrol yakni 445,87 $\mathrm{U} / \mathrm{g}(\mathrm{FW})$. Persentase penurunan tersebut berkisar 93$97 \%$, namun pada perlakuan variasi kombinasi massa dan lama memberikan hasil yang tidak berbeda nyata. Aktivitas PPO terendah terjadi pada perlakuan kombinasi massa $100 \mathrm{~g}$ dan lama 1 menit.

Adanya perbedaan efek aktivitas PPO kemungkinan besar disebabkan oleh adanya perbedaan kadar air biji kakao akibat perlakuan steam blanching. Adanya perbedaan kadar air ini erat kaitannya dengan perbedaan penyerapan air selama steam blanching, seperti yang dilaporkan oleh Dewanto et al. (2002) bahwa pada blanching terjadi pelunakan jaringan akibat adanya penyerapan air yang menyebabkan terjadinya peningkatan massa. Selain kadar air, $\mathrm{pH}$ juga mempengaruhi aktivitas PPO dimana dari hasil penelitian ini menunjukkan bahwa semakin lama steam blanching, $\mathrm{pH}$ biji kakao semakin tinggi yakni berkisar dari 7,09-7,19. Putra et al. (2012) melaporkan bahwa nilai $\mathrm{pH}$ yang optimal untuk PPO adalah 5,42. Berbeda halnya pada buah leci yang memiliki $\mathrm{pH}$ optimal 6,5 sampai 7,0 dan tidak terdeteksi adanya aktivitas PPO pada $\mathrm{pH}$ 2,5 atau 9,5 (Mizobutsi et al., 2010).

Secara umum, perlakuan steam blanching belum mampu menginaktivasi PPO walaupun suhu biji mencapai $99,5^{\circ} \mathrm{C}$. Padahal seperti yang dilaporkan oleh Queiroz et al. (2008) bahwa pada suhu $90^{\circ} \mathrm{C}$ saja dapat menyebabkan terjadinya inaktivasi enzim, namun rusaknya aktivitas katalitiknya membutuhkan waktu tergantung pada bahannya (Xiao et al., 2014). Aktivitasnya akan semakin menurun dengan meningkatnya suhu dan lama pemanasan (Wang et al., 2017). Dalam penelitiannya pada jus nanas Chutintrasri dan Noomhorm (2006) menyebutkan bahwa perlakuan pemanasan mampu menurunkan aktivitas PPO sebesar $60 \%$ pada suhu $40-60^{\circ} \mathrm{C}$ selama 30 menit. Berbeda halnya seperti yang dilaporkan oleh Terefe et al. (2010) bahwa meskipun telah diberi perlakuan panas pada suhu $100^{\circ} \mathrm{C}$ selama 30 menit, PPO pada jus strawberry masih nampak stabil. Pada biji kakao, Lee et al. (2003) menyebutkan bahwa suhu optimum PPO sebesar $45^{\circ} \mathrm{C}$ dan relatif stabil pada kisaran suhu $50-70^{\circ} \mathrm{C}$. Hasil

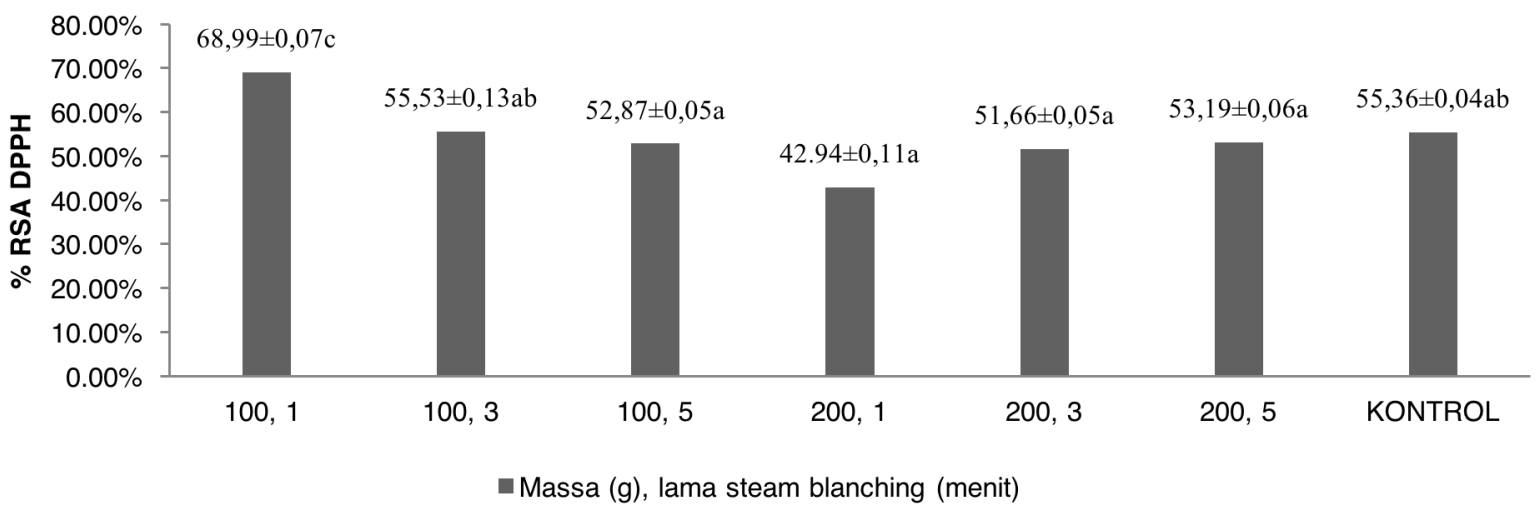

Figur 3. Nilai \% RSA (Radical Scavenging Activity) biji kakao akibat perlakuan kombinasi variasi massa dan lama steam blanching.

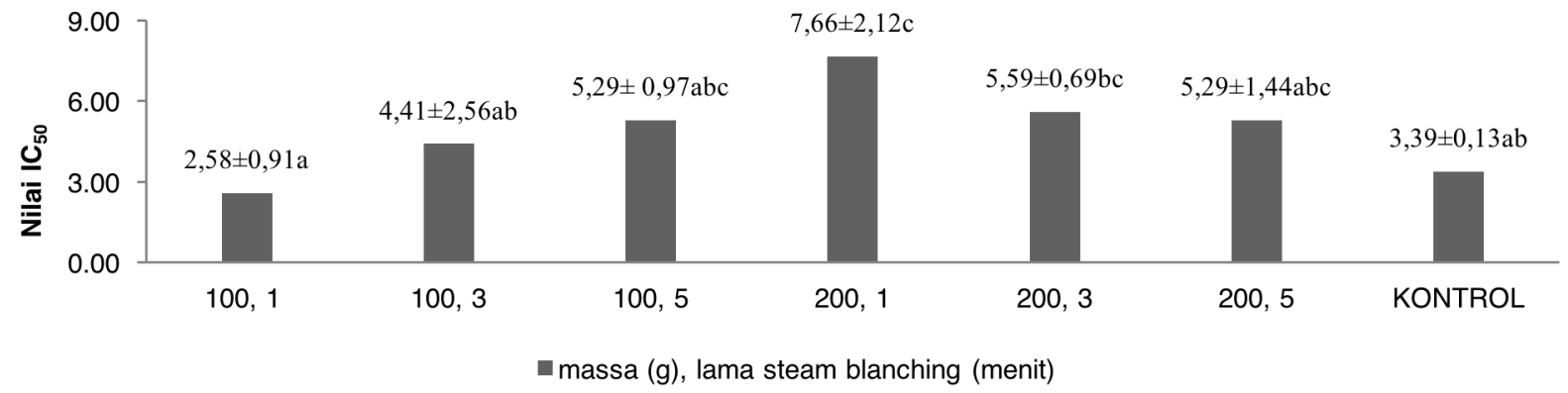

Figur 4. Nilai $I_{50}$ biji kakao akibat perlakuan kombinasi variasi massa dan lama steam blanching. 
penelitian Putra et al. (2012) juga menunjukkan bahwa kondisi optimum aktivitas PPO pada suhu $53,43^{\circ} \mathrm{C}$ dan peningkatan suhu yang melampaui suhu tertentu (suhu optimal) juga akan menurunkan aktivitas enzim akibat laju kerusakan enzim melampaui laju aktivitas enzim. Adanya perbedaan aktivitas PPO antara biji yang mengalami perlakuan steam blanching dan kontrol juga dapat dilihat dari perbedaan warna dimana warna kecoklatan gelap pada menunjukkan biji kakao telah mengalami oksidasi. Hal ini ditunjukkan oleh nilai $L^{*}$ dan $b^{\star}(+)$ pada kontrol yang lebih tinggi dibandingkan biji kakao steam blanching.

\section{Kandungan total polifenol biji kakao steam blanching} Hasil penelitian kandungan total polifenol biji kakao steam blanching disajikan pada Figur 2. Figur tersebut menunjukkan bahwa perlakuan steam blanching dengan kombinasi massa $100 \mathrm{~g}$ selama 1 dan 3 menit serta massa $200 \mathrm{~g}$ selama 5 menit mampu meningkatkan kandungan total polifenol sebesar 3-27\% yakni dengan kisaran 74,33-92,15 mg EAG/g sampel bubuk kakao bebas lemak (DS) dari kontrol sebesar $72,63 \mathrm{mg}$ EAG/g DS. Hal yang sama juga dilaporkan oleh Pujimulyani et al. (2012) pada kunyit putih dimana perlakuan blanching dalam media asam sitrat $0,05 \%$, $100^{\circ} \mathrm{C}$ selama 5 menit mampu meningkatkan kadar fenol total sebesar $29 \%$ bahkan pada penelitian yang dilakukan oleh Tamaroh et al. (2017) pada uwi ungu menunjukkan bahwa perlakuan blanching mampu meningkatkan kadar total polifenol sebanyak 1,3-1,6 kali lipat.

Hasil penelitian ini menunjukkan bahwa perlakuan steam blanching mampu me-recover senyawa polifenol pada biji kakao seperti pada perlakuan water blanching yang telah dilaporkan oleh Tomas-Barberán et al. (2007) dan Menon et al. (2015). Adanya peningkatan kandungan total fenolik akibat perlakuan steam blanching kemungkinan besar disebabkan oleh adanya senyawa polifenol yang tidak mengalami oksidasi enzimatis seperti yang terlihat pada Figur 1 dan 2. Dari figur tersebut terlihat bahwa aktivitas PPO selaras dengan kandungan total polifenolnya. Hal ini menunjukkan bahwa kandungan total polifenol dipengaruhi oleh aktivitas PPO yang juga diperkuat oleh data korelasi pada Figur 6, sehingga adanya perlakuan steam blanching dalam menurunkan aktivitas PPO dapat mampu mempertahankan bahkan meningkatkan antioksidan alami polifenol biji kakao. Hal lain kemungkinan diduga oleh adanya perubahan senyawa kurang aktif menjadi aktif (Kim et al., 2010) seperti adanya kerusakan tanin menjadi fenol yang lebih sederhana (Pujimulyani et al., 2012), konversi fenolat larut menjadi bentuk yang lebih larut (Ramadhan \& Aminah, 2014).

\section{Aktivitas penangkapan radikal bebas}

Hasil penelitian aktivitas penangkapan radikal bebas DPPH pada biji kakao steam blanching disajikan pada Figur 3. Perlakuan steam blanching mampu meningkatkan aktivitas antioksidan dibandingkan kontrol. Aktivitas antioksidan tertinggi terjadi pada kombinasi perlakuan massa $100 \mathrm{~g}$ selama 1 menit yakni sebesar $68,99 \%$ dibandingkan kontrol yakni 55,36\%, trend ini sebanding dengan hasil analisa kandungan total polifenol (Figur 2). Adanya fenomena tersebut disebabkan oleh adanya molekul polifenol kelompok flavonoid gugus $\mathrm{OH}$ yang bertindak sebagai donor $\mathrm{H}^{+}$ sehingga paling berperan terhadap aktivitas antioksidan. Jadi semakin banyak kandungan total polifenol maka semakin banyak gugus $\mathrm{OH}$ yang mendonorkan atom $\mathrm{H}^{+}$ sehingga aktivitas antioksidan dapat semakin tinggi (Supriyanto et al., 2014).

Selain itu, besarnya aktivitas antioksidan juga bisa dinilai dari nilai $I_{50}$ yaitu konsentrasi larutan sampel yang dibutuhkan untuk menangkal $50 \%$ radikal bebas $\mathrm{DPPH}$, dimana nilai $\mathrm{IC}_{50}$ yang semakin rendah akan menunjukkan aktivitas antioksidan yang semakin tinggi sehingga keefektifannya menjadi penangkap radikal yang lebih baik terjadi pada nilai $\mathrm{IC}_{50}$ yang lebih rendah (Molyneux, 2004). Pada Figur 4 memperlihatkan nilai $\mathrm{IC}_{50}$ mencapai $2,58 \mathrm{ml} / \mathrm{l}$ pada perlakuan kombinasi massa $100 \mathrm{~g}$ selama 1 menit dibandingkan dengan kontrol yakni 3,39 ml/l. Dari hasil penelitian ini juga menunjukkan bahwa aktivitas antioksidan biji kakao lebih tinggi dibandingkan dengan BHT dan asam askorbat, dimana aktivitas penangkapan radikal bebas DPPH (\%) dan nilai $\mathrm{IC}_{50}(\mathrm{mg} / \mathrm{L})$ untuk BHT dan asam askorbat berturut-turut adalah sebesar 20,85; 18,64; dan 20,$46 ; 13,90$. Hal ini menunjukkan bahwa penggunaan steam blanching dapat menurunkan aktivitas PPO sehingga dapat meningkatkan kadar total polifenol dan aktivitas antioksidan biji kakao.

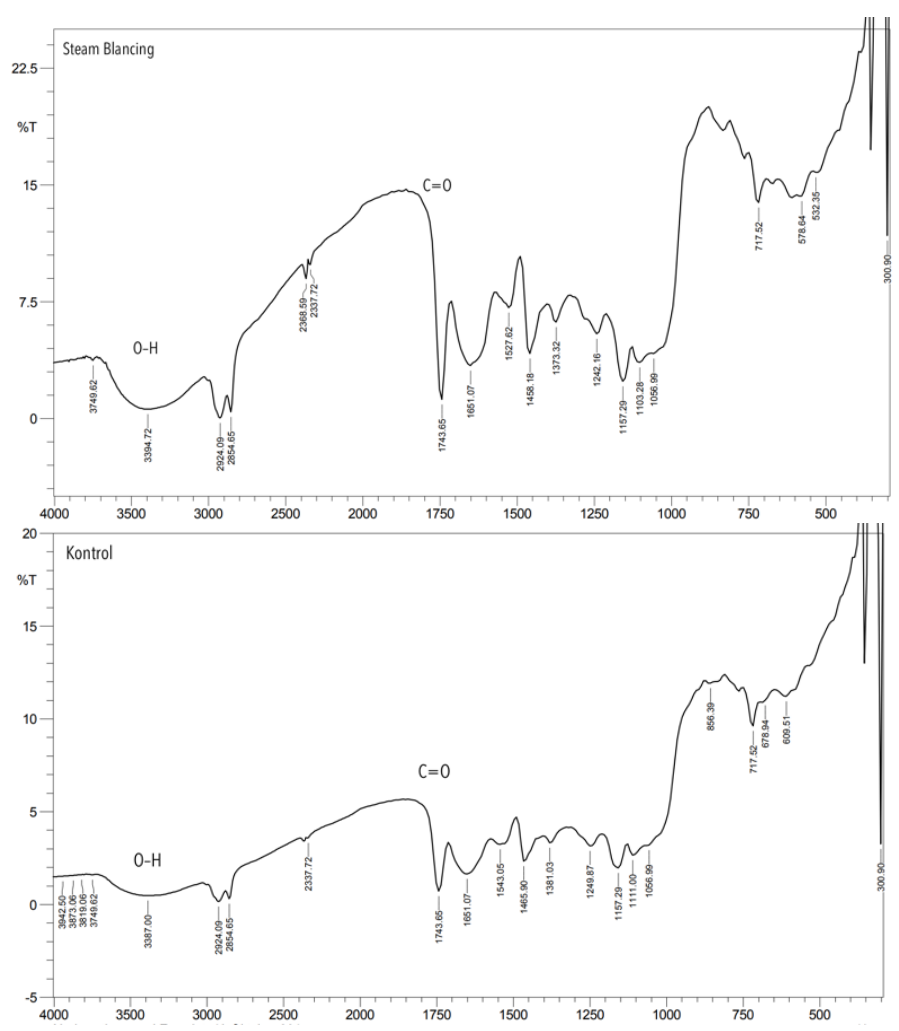

Figur 5. Perbandingan spektrum FTIR pada biji kakao perlakuan steam blanching (100 g; 1 menit) dan biji kakao kontrol 


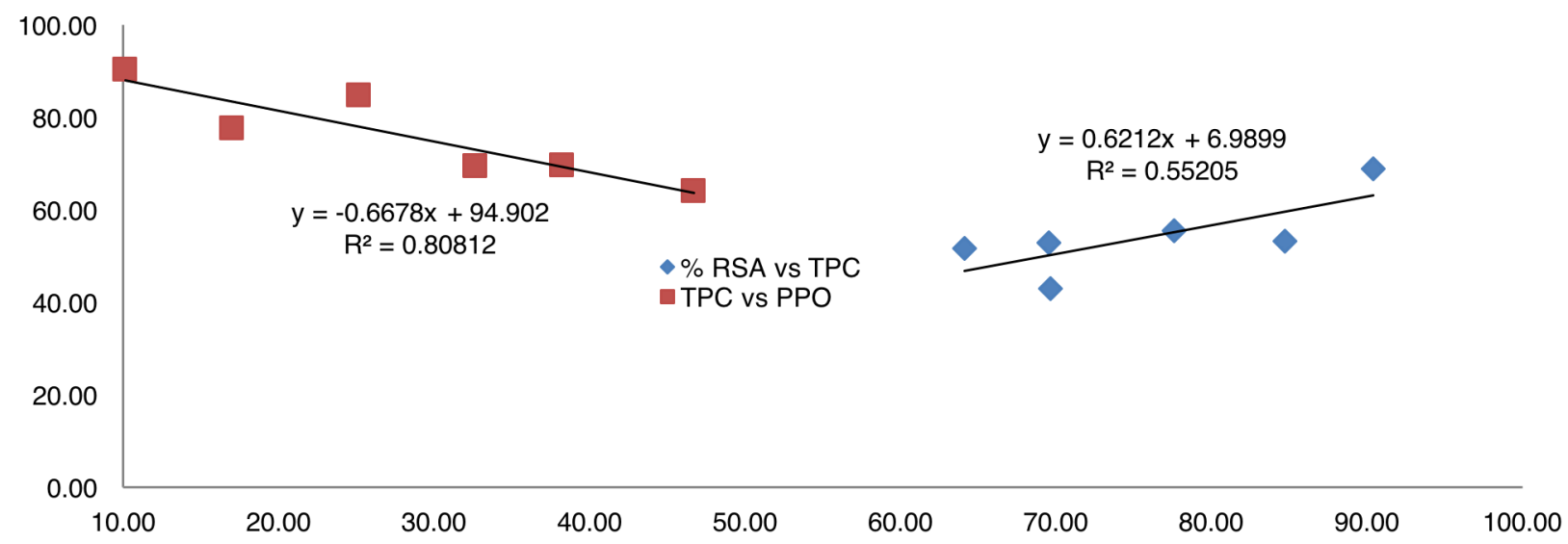

Figur 6. Nilai korelasi kandungan total polifenol (TPC) dengan aktivitas PPO serta aktivitas antioksidan (\%RSA) dengan kandungan total polifenol (TPC)

Analisa gugus fungsional

Spektrum FTIR biji kakao steam blanching dan kontrol dapat dilihat pada Figur 5. Spektrum IR merupakan jenis spektrum yang bersifat spesifik dan dapat memberikan informasi mengenai gugus fungsional suatu molekul (Hu et al., 2016). Analisa gugus fungsional dengan FTIR dapat digunakan untuk memprediksi jumlah gugus $\mathrm{O}-\mathrm{H}$ dalam molekul senyawa polifenol dan jumlah gugus $(\mathrm{C}=\mathrm{O})$ dalam molekul senyawa quinon dengan menghitung nilai absorbansinya berdasarkan Hukum Lambert-Beer dimana nilai absorbansi sebanding dengan konsentrasi, sehingga secara tidak langsung, dapat diketahui besarnya oksidasi senyawa polifenol menjadi quinon oleh adanya aktivitas PPO (Queiroz et al., 2008) .

Figur 5 memperlihatkan bahwa jumlah gugus $\mathrm{O}-\mathrm{H}$ (polifenol) ditunjukkan pada frekuensi $3500-3200 \mathrm{~cm}^{-1}$, sedangkan jumlah gugus $\mathrm{C}=\mathrm{O}$ (quinon) ditunjukkan pada frekuensi $1760-1690 \mathrm{~cm}^{-1}$. Dari figur tersebut terlihat bahwa nilai transmittansi (\%) yang terukur untuk gugus $\mathrm{O}-\mathrm{H}$ dan $\mathrm{C}=\mathrm{O}$ untuk biji kakao perlakuan blanching dengan kontrol yakni berturut-turut adalah 0,$528 ; 0,474$ (gugus $\mathrm{O}-\mathrm{H}$ ) dan 1,216; 0,707 (gugus $\mathrm{C}=\mathrm{O}$ ). Dari hasil tersebut, berdasarkan Hukum Lambert beer diperlihatkan bahwa perbandingan antara jumlah gugus $\mathrm{OH}$ dalam molekul senyawa polifenol dan gugus $\mathrm{C}=\mathrm{O}$ dalam molekul senyawa quinon biji kakao steam blanching lebih tinggi dibandingkan kontrol. Hal ini mengindikasikan bahwa oksidasi polifenol oleh aktivitas PPO lebih besar terjadi pada pada kontrol.

Korelasi aktivitas PPO vs kandungan total polifenol dan kandungan total polifenol vs aktivitas antioksidan

Figur 6 merupakan grafik yang menyatakan hubungan antara kandungan total polifenol (TPC) dan aktivitas PPO dengan nilai korelasi sebesar $r^{2}=0,808$. Hasil ini menunjukkan bahwa $80,8 \%$ kandungan total polifenol dipengaruhi oleh aktivitas PPO dengan persamaan $y=-0,667 x+94,9$ yang berarti bahwa jika aktivitas PPO meningkat sebesar satu satuan maka kandungan total polifenol akan menurun sebesar 0,667 satuan. Selain itu pada Figur 6 juga menunjukkan hubungan antara aktivitas antioksidan (radical scavenging activity, RSA dalam \%) dengan kandungan total polifenol (TPC) dengan nilai korelasi $r^{2}=0,552$. Hasil ini juga menunjukkan bahwa 55,2 \% aktivitas antioksidan berasal dari total polifenol sedangkan 44,8 $\%$ yang lain kemungkinan berasal dari senyawa lain selain polifenol. Dari persamaan $(y=0,621 x+6,989)$ mengindikasikan bahwa jika kandungan total polifenol meningkat sebesar satu satuan maka aktivitas antioksidan juga akan meningkat sebesar 0,621.

\section{Kesimpulan}

Berdasarkan hasil penelitian yang diperoleh, perlakuan steam blanching dengan massa $100 \mathrm{~g}$ selama 1 menit mampu menurunkan aktivitas PPO sebesar 93$97 \%$ pada biji kakao, meningkatkan kandungan total polifenol sebesar 3-27\% serta meningkatkan aktivitas antioksidan dibandingkan dengan tanpa perlakuan steam blanching (kontrol). Jadi, perlakuan steam blanching dapat dijadikan sebagai salah satu alternatif proses pengolahan dalam mempertahankan antioksidan alami polifenol biji kakao.

\section{Daftar Pustaka}

Abu-Ghannam, N., Jaiswal, A.K. 2015. Blanching as a treatment process: effect on polyphenol and antioxidant capacity of cabbage. Elsevier/ Academic Press. London UK.

Amanto, B.S., Siswanti, S., Atmaja, A. 2015. Kinetika pengeringan temu giring (Curcuma heyneana valeton \& van zijp) menggunakan cabinet dryer dengan perlakuan pendahuluan blanching. Jurnal Teknologi Hasil Pertanian 8(2):107-114.

Association of Official Analytical Chemists (AOAC). 1997. Official Methods of Analysis of the association of analytical chemists. AOAC. Washington, DC.

Ayu, D.C., Yuwono, S.S. 2013. Pengaruh suhu blansing dan lama perendaman terhadap sifat fisik kimia tepung kimpul (Xanthosoma Sagittifolium). Jurnal Pangan dan Agroindustri 2(2), 110-120. 
Bamidele, O., Fasogbon, M., Adebowale, O., Adeyanju, A. 2017. Effect of blanching time on total phenolic, antioxidant activities and mineral content of selected green leafy vegetables. Current Journal of Applied Science and Technology 24(4): 1-8. DOI:10.9734/CJAST/2017/34808.

Benlloch-Tinoco, M., Igual, M., Rodrigo, D., MartínezNavarrete, N. 2013. Comparison of microwaves and conventional thermal treatment on enzymes activity and antioxidant capacity of kiwifruit puree. Innovative Food Science \& Emerging Technologies 19: 166-172. DOI :10.1016/ j.ifset.2013.05.007

Bonvehi, J.S., Coll, F.V. 1997. Evaluation of bitterness and astringency of polyphenolic compounds in cocoa powder. Food Chemistry 60(3): 365-370.

Burda, S., Oleszek, W. 2001. Antioxidant and antiradical activities of flavonoids. Journal of Agricultural and Food Chemistry 49(6): 2774-2779. DOI:10.1021/ jf001413m.

Camu, N., De Winter, T., Addo, S.K., Takrama, J.S., Bernaert, H., De Vuyst, L. 2008. Fermentation of cocoa beans: influence of microbial activities and polyphenol concentrations on the flavour of chocolate. Journal of the Science of Food and Agriculture 88(13): 2288-2297. DOI:10.1002/ jsfa.3349.

Chutintrasri, B., Noomhorm, A. 2006. Thermal inactivation of polyphenoloxidase in pineapple puree. LWT-Food Science and Technology 39(5): 492-495. DOI:10.1016/j.Iwt.2005.04.006.

Dewanto, V., Wu, X., Liu, R.H. 2002. Processed sweet corn has higher antioxidant activity. Journal of Agricultural and Food Chemistry 50(17): 49594964. DOI:10.1021/jf0255937

Hu, Y., Pan, Z.J., Liao, W., Li, J., Gruget, P., Kitts, D.D., Lu, X. 2016. Determination of antioxidant capacity and phenolic content of chocolate by attenuated total reflectance-fourier transformed-infrared spectroscopy. Food Chemistry 202: 254-261. DOI:10.1016/j.foodchem.2016.01.130

Ioannou, I., Hafsa, I., Hamdi, S., Charbonnel, C., Ghoul, M. 2012. Review of the effects of food processing and formulation on flavonol and anthocyanin behaviour. Journal of Food Engineering 111(2): 208-217. DOI:10.1016/j.jfoodeng.2012.02.006

Kim, T.J., Silva, J.L., Kim, M.K., Jung, Y.S. 2010. Enhanced antioxidant capacity and antimicrobial activity of tannic acid by thermal processing. Food Chemistry 118(3): 740-746. DOI:10.1016/ j.foodchem.2009.05.060

Lee, K.W., Kim, Y.J., Lee, H.J., Lee, C.Y. 2003. Cocoa has more phenolic phytochemicals and a higher antioxidant capacity than teas and red wine. Journal of Agricultural and Food Chemistry 51(25): 7292-7295. DOI:10.1021/jf0344385

Magrone, T., Russo, M.A., Jirillo, E. 2017. Cocoa and dark chocolate polyphenols: from biology to clinical applications. Frontiers in Immunology (8). DOI:10.3389/fimmu.2017.00677
Mazzeo, T., N'Dri, D., Chiavaro, E., Visconti, A., Fogliano, V., Pellegrini, N. 2011. Effect of two cooking procedures on phytochemical compounds, total antioxidant capacity and colour of selected frozen vegetables. Food Chemistry 128(3): 627-633. DOI:10.1016/j.foodchem. 2011.03.070

Menon, A.S., Hii, C.L., Law, C.L., Suzannah, S., Djaeni, M. 2015. Effects of water blanching on polyphenol reaction kinetics and quality of cocoa beans. In AIP Conference Proceedings (1699): 030006. DOI:10.1063/1.4938291

Misnawi, S.J., Nazamid, S., Jamilah, B. 2002. Activation of remaining key enzymes in dried underfermented cocoa beans and its effect on aroma precursor formation. Food Chemistry 78(4): 407417.

Mizobutsi, G.P., Finger, F.L. 2010. Effect of pH and temperature on peroxidase and polyphenoloxidase activities of litchi pericarp. Scietia Agricola 67(2): 213-217.

Molyneux, P. 2004. The use of the stable free radical diphenylpicrylhydrazyl (DPPH) for estimating antioxidant activity. Songklanakarin Journal of Science and Technology 26(2): 211-219.

Nurhuda, H.H., Maskat, M.Y., Mamot, S., Aiq, J., Aminah, A. 2013. Effect of blanching on enzyme and antioxidant activities of rambutan (Nephelium lappaceum) peel. International Food Research Journal 20(4):1725-1730.

Noor-Soffalina, S.S., Jinap, S., Nazamid, S., Nazimah, S.A.H. 2009. Effect of polyphenol and $\mathrm{pH}$ on cocoa maillard-related flavour precursors in a lipidic model system. International Journal of Food Science \& Technology 44(1): 168-180. DOI:10.1111/j.1365-2621.2008.01711.x.

Pujimulyani, D., Raharjo, S., Marsono, Y., Santoso, U. 2012. Pengaruh blanching terhadap aktivitas antioksidan, kadar fenol, flavonoid, dan tanin terkondensasi kunir putih (Curcuma mangga Val). Jurnal Agritech 30(3): 141-147

Putra, G.P.G., Wartini, N.M., Anggreni, A.A.M.D. 2012. Karakterisasi enzim polifenol oksidase biji kakao (Theobroma cacao Linn.) Characterization of Polyphenol Oxidase Enzyme of Cocoa Beans (Theobroma cacao Linn). Jurnal Agritech 30(03):152-157. DOI:10.22146/agritech.9667

Queiroz, C., Mendes Lopes, M.L., Fialho, E., ValenteMesquita, V.L. 2008. Polyphenol Oxidase: characteristics and mechanisms of browning control. Food Reviews International 24(4): 361375. DOI:10.1080/87559120802089332

Ramadhan, T., Aminah, S. 2014. Pengaruh pemasakan terhadap kandungan antioksidan sayuran. Buletin Pertanian Perkotaan 4(2):7-13.

SNI, 2008. SNI 2323-biji kakao. Badan Standardisasi Nasional. Jakarta.

Supriyanto, S., Haryadi, H., Rahardjo, B., Marseno, D.W. 2014. Perubahan suhu, kadar air, warna, kadar polifenol dan aktivitas antioksidatif kakao selama penyangraian dengan enerji gelombang mikro. 
Jurnal Agritech 27(01): 18-26. DOI:10.22146/ agritech.9489.

Tamaroh, S. 2017. The effect of blanching time of purple yam (Dioscorea Alata L) on anthocyanins content and antioxidant activity. The International Journal of Science \& Technoledge 8(5): 83-88.

Terefe, N.S., Yang, Y.H., Knoerzer, K., Buckow, R., Versteeg, C. 2010. High pressure and thermal inactivation kinetics of polyphenol oxidase and peroxidase in strawberry puree. Innovative Food Science \& Emerging Technologies 11(1): 52-60. DOI:10.1016/j.ifset.2009.08.009.

Tomas-Barberán, F.A., Cienfuegos-Jovellanos, E., Marín, A., Muguerza, B., Gil-Izquierdo, A., Cerdá, B.Espín, J.C. 2007. A new process to develop a cocoa powder with higher flavonoid monomer content and enhanced bioavailability in healthy humans. Journal of Agricultural and Food Chemistry 55(10): 3926-3935. DOI:10.1021/ jf070121j.

Wang, J., Yang, X.H., Mujumdar, A.S., Wang, D., Zhao, J.H., Fang, X.M., Xiao, H.W. 2017. Effects of various blanching methods on weight loss, enzymes inactivation, phytochemical contents, antioxidant capacity, ultrastructure and drying kinetics of red bell pepper (Capsicum annuum L.). LWT 77: 337-347. DOI:10.1016/j.Iwt. 2016.11.070.
Wollgast, J., Anklam, E. 2000. Review on polyphenols in theobroma cacao: changes in composition during the manufacture of chocolate and methodology for identification and quantification. Food Research International 33(6): 423-447. DOI:10.1016/ S0963-9969(00)00068-5.

Xiao, H.W., Bai, J.W., Sun, D.W., Gao, Z.J. 2014. The application of superheated steam impingement blanching (SSIB) in agricultural products processing-A review. Journal of Food Engineering 132: 39-47. DOI:10.1016/ j.jfoodeng.2014.01.032.

Xiao, H.W., Pan, Z., Deng, L.Z., El-Mashad, H.M., Yang, X.H., Mujumdar, A.S., Zhang, Q. 2017. Recent developments and trends in thermal blanching - A comprehensive review. Information Processing in Agriculture 4(2): 101-127. DOI:10.1016/ j.inpa.2017.02.001. 